\title{
Current prevalence of Helicobacter pylori infection in patients with dyspepsia treated in Warsaw, Poland
}

\author{
Tadeusz Tacikowski', Sa’eed Bawa², Danuta Gajewska², Joanna Myszkowska-Ryciak², Jacek Bujko², \\ Grażyna Rydzewska ${ }^{1}$ \\ ${ }^{1}$ Clinic of Gastroenterology, Central Clinical Hospital of the Ministry of Internal Affairs, Warsaw, Poland \\ ${ }^{2}$ Department of Dietetics, Faculty of Human Nutrition and Consumer Sciences, Warsaw University of Life Sciences, Warsaw, \\ Poland
}

Key words: Helicobacter pylori, Helicobacter pylori prevalence.

Address for correspondence: Tadeusz Tacikowski MD, PhD, Clinic of Gastroenterology, Central Clinical Hospital of the Ministry of Internal Affairs, 137 Wołoska St, 02-507 Warsaw, Poland, phone: +48 607170 263, e-mail: ttacikowski@gmail.com

\begin{abstract}
Introduction: The prevalence of Helicobacter pylori $(\mathrm{Hp})$ infection in patients with dyspepsia has important clinical and epidemiological implications. However, the current prevalence of $\mathrm{Hp}$ infection among patients within Poland is unknown; the last data were collected a decade ago and the majority of previous studies showed the prevalence to be between $60 \%$ and $100 \%$.

Aim: To establish the current prevalence of Hp infection among patients with dyspepsia in Warsaw, Poland.

Material and methods: The study group comprised 148 patients (126 women and 22 men) with dyspepsia, treated in two outpatient clinics in Warsaw. The mean age in the group that tested positive for Hp was 45.8 years (SD = 14.86; median = 51; $\min =19 ; \max =64)$. They were tested for Hp infection with a urea breath test that uses $13 \mathrm{C}$-enriched urea and isotope ratio mass spectrometry.

Results: Helicobacter pylori infection was found in 53 patients (44 women and 9 men), i.e. in $35.8 \%$ of the whole study group. We did not find any significant relationship between $\mathrm{Hp}$ infection and the patients' age, gender, or their body mass index.

Conclusions: The current prevalence of $\mathrm{Hp}$ infection among patients with dyspepsia treated in Warsaw is $35.8 \%$. However, our data suggest almost a two-fold fall in the prevalence of Hp infection compared to the previous Polish studies.
\end{abstract}

\section{Introduction}

Dyspepsia is defined as a chronic or recurrent upper-abdominal discomfort or pain [1-3]. There are two types of dyspepsia: organic and functional. The main causes of organic dyspepsia are: gastroesophageal reflux, chronic peptic ulcer disease, and malignancy [4, 5]. Among the pathogenic factors of functional dyspepsia are: genetic predisposition, Helicobacter pylori ( $\mathrm{Hp}$ ) infections, inflammation, and psychosocial factors. Currently, it is assumed that lack of clinical improvement after successful eradication treatment in $\mathrm{Hp}$-infected dyspeptic patients is indicative of functional dyspepsia, while reduction of symptoms as a result of the treatment suggests $\mathrm{Hp}$-associated dyspepsia, which is a type of organic dyspepsia. Eradication treatment is a first-line treatment for Hp-infected dyspeptic patients [6, 7]. Known as "test and treat", the current guidelines for dealing with dyspeptic patients recommend testing for $\mathrm{Hp}$ infection. In $\mathrm{Hp}$-in- fected patients below 50 years of age who do not display alarming symptoms nor have a family history of gastrointestinal cancer eradication treatment is recommended. It should also be administered in $\mathrm{Hp}$-infected patients in regions where the prevalence of $\mathrm{Hp}$ is at least $10 \%$ of the population. In patients with alarming symptoms and older than 55 years, a gastroscopy should be carried out [8, 9].

The prevalence of dyspepsia in the total population is high and reaches 34\%, according to Castillo's USbased study [10].

The current prevalence of $\mathrm{Hp}$ infection among patients within Poland is unknown; the last data were collected a decade ago and the majority of existing studies tested the general population.

\section{Aim \\ The aim of the present study was to establish the current prevalence of $\mathrm{Hp}$ infection in patients with}


dyspepsia treated in Warsaw (Poland) using the urea breath test (UBT).

\section{Material and methods}

The study group comprised 148 patients (126 women and 22 men) with dyspepsia. The mean age in this group was 46 years $(S D=14.45 ;$ median $=50 ;$ $\min =$ 19 ; $\max =64$ ). All subjects were treated in the Clinic of Gastroenterology of the Central Clinical Hospital of the Ministry of Internal Affairs in Warsaw and the Department of Dietetics, Faculty of Human Nutrition and Consumer Sciences, Warsaw University of Life Sciences. Prior to the study, all subjects gave informed consent to take part in the study by signing an appropriate form. The Regional Ethical Review Board of the Clinical Hospital of the Ministry of Internal Affairs (Warsaw, Poland) approved the study, and it was performed according to the guidelines of the Declaration of Helsinki 1975.

The subjects were tested for Hp infection with the UBT that uses $75 \mathrm{mg}$ 13C-enriched urea containing 99\% of atoms of carbon-13, produced by INFAI (Bochun, Germany), which was dissolved in $200 \mathrm{ml}$ of orange juice. Breath samples were taken in two capped breath containers before drinking the test solution and $30 \mathrm{~min}$ after. Thus, four breath samples were taken altogether, two being control samples. The samples were evaluated in isotope ratio mass spectrometry (IRMS) using an Automated Breath Carbon Analyser produced by Sercon (UK). A result was considered positive, i.e. indicative of the infection, when the increase of $13 \mathrm{CO}_{2}$ in the breath was $>4 \%$ compared to the baseline value $[11,12]$.

\section{Statistical analysis}

The prevalence of $\mathrm{Hp}$ infection was calculated as a proportion of patients who scored positive in the urea breath test (UBT), relative to all patients participating in the study. For additional (control) statistical analy-

Table I. The prevalence of Helicobacter pylori $(\mathrm{Hp})$ infection in different age brackets

\begin{tabular}{lccc}
$\begin{array}{l}\text { Age } \\
\text { [years] }\end{array}$ & $\begin{array}{c}\text { Hp present } \\
\mathbf{N = 5 3}\end{array}$ & $\begin{array}{c}\text { Hp absent } \\
\mathbf{N = 9 5}\end{array}$ & $\begin{array}{c}\text { Percent of subjects } \\
\text { infected }\end{array}$ \\
\hline $18-19$ & 1 & 0 & $\begin{array}{c}\text { Proportion not calculated } \\
\text { due to low number of } \\
\text { subjects }\end{array}$ \\
\hline $20-29$ & 10 & 16 & 38.5 \\
\hline $30-39$ & 5 & 9 & 35.7 \\
\hline $40-49$ & 4 & 12 & 25 \\
\hline $50-59$ & 17 & 16 & 51.5 \\
\hline $60-69$ & 9 & 19 & 32.1 \\
\hline
\end{tabular}

ses, we used IBM SPSS software (version 22, Armonk, NY: IBM Corp.). In all tests, we considered values below 0.05 to be statistically significant. The spectrometer was properly certified by competent authorities.

\section{Results}

Helicobacter pylori infection was found in 53 patients (44 women and 9 men), i.e. in $35.8 \%$ of the study group, comprising 148 people. This principal finding was followed by additional statistical analyses aiming to establish whether certain factors (i.e. age, body mass index, and gender) were significantly related to the prevalence of $\mathrm{Hp}$ infection. We did not expect such effects to occur; the character of these additional analyses was mainly exploratory.

The mean age in the group that tested positive for $\mathrm{Hp}$ was 45.8 years $(\mathrm{SD}=14.86$; median $=51$; $\min =19 ; \max =64)$. In turn, the mean age of the patients that proved to be $\mathrm{Hp}$ negative was 46.1 years $(\mathrm{SD}=14.29 ;$ median $=48 ; \min =21 ; \max =64)$. We wanted to check whether there was a systematic difference between infected and uninfected groups in terms of age. The Shapiro-Wilk test showed that the participants' age deviated from the normal distribution ( $p$ < 0.005). That is why we used a non-parametric Mann-Whitney $U$ test to analyse these data. We found that the age of the Hp-positive group did not differ significantly from the age of the Hp-negative group $\left(U=1652.5 ; n_{1}=46 ; n_{2}=72 ; p=0.99\right.$; twotailed). We also broke down the study group by age and tested whether the participants' age was significantly related to Hp prevalence. The $\chi^{2}$ test used to analyse these data did not show any significant relationship between infection prevalence and five different age-ranges $\left(\chi^{2}=4.12 ; p=0.39 ; N=117 ; \mathrm{d} f=4\right)$. It is noteworthy that the $<20$-year-old group was excluded from the above analysis due to the number of subjects being too low (Table I).

The average $\mathrm{BMI}$ in patients with $\mathrm{Hp}$ infection was $25.2 \mathrm{~kg} / \mathrm{m}^{2}(\mathrm{SD}=3.83$; median $=24.9$; $\min =17.6$; $\max =32.7)$, whereas in the group without $\mathrm{Hp}$ it was 25.2 (SD = 4.96; median $=24.35 ;$ $\min =16.8 ; \max =$ 39). The Shapiro-Wilk test showed BMI did not deviate significantly from the normal distribution $(p>0.07)$, so a two-sample $t$-test (two-tailed) was used to analyse these data. The BMI of patients in the infected group did not differ significantly from the BMI of patients from the uninfected group $\left(t_{111}=0.12 ; p=0.91\right)$.

Finally, we checked whether $\mathrm{Hp}$ infection significantly depended on the patients' gender. In the Hp positive group there were 44 females and 9 males, whereas in the $\mathrm{Hp}$ negative group there were 82 females and 13 males. There was no significant relationship be- 
tween $\mathrm{Hp}$ infection and the patients' gender $\left(\chi^{2}=0.29\right.$; $p=0.59 ; N=148 ; \mathrm{d} f=1)$.

\section{Discussion}

The aim of this study was to establish the current prevalence of $\mathrm{Hp}$ infection among patients with dyspepsia in Warsaw (Poland), using the UBT. In a group of 148 patients, we found that $35.8 \%$ tested positive for $\mathrm{Hp}$.

Helicobacter pylori infection is one of the most common infections in the world but its transmission is not even across different parts of the globe. Studies conducted in highly developed countries revealed a similar or lower prevalence of $\mathrm{Hp}$ infection as compared with our findings. In a Dutch serologic study the prevalence of Hp infection in blood donors was $31.7 \%$ [13]. In Cyprus, a PCR study revealed the prevalence of $\mathrm{Hp}$ infection in subjects with dyspepsia to be $39.8 \%$ [14]. In Belgium, Hp infection was found in only $17 \%$ of patients with dyspepsia [15]. A similar prevalence rate was revealed in a group of people with dyspepsia in Denmark [16]. In a British study, serologic features of $\mathrm{Hp}$ infection were discovered in $37 \%$ of dyspepsia patients in primary care [17]. Nandurkar et al. (Australia) established the prevalence of $\mathrm{Hp}$ in subjects with dyspepsia at only $15.4 \%$ [18]. In contrast, the prevalence of $\mathrm{Hp}$ infection in patients with dyspepsia in developing countries is significantly higher, reaching $86 \%$ in Bhutan [19], 75.5\% in Morocco [20], 76.5\% in Kazakhstan [21], and $62 \%$ in India [22]. Thus, it may be assumed that as a country develops economically and improves its hygiene, the prevalence of the infection decreases.

Studies carried out previously in Poland revealed a very high prevalence of $\mathrm{Hp}$ infection ( $75 \%$; see Table II), much higher than in highly developed European countries. For example, in the study published by Piotrowicz et al. [23], the prevalence of $\mathrm{Hp}$ infection in pa- tients with dyspepsia was $69.8 \%$, which is much higher than in our study group. The study examined a different population, of the region of Olsztyn in Poland, which is a smaller city located in a mostly rural area, and the material was collected in 2003-2005. Studies by Celiński et al. [24] suggest that the smaller the town or village of the subjects' residence, the higher the prevalence of Hp infection. The studies, carried out in 2000-2003, showed a higher prevalence of $\mathrm{Hp}$ infection in towns (95\%) than in cities (74\%), with the prevalence of $\mathrm{Hp}$ infection in Warsaw standing at almost $88 \%$. A lower prevalence of $\mathrm{Hp}$-dependant gastritis in patients with functional dyspepsia, i.e. 54.9\%, was found in a 1999 multi-centre study [25]. In turn, a 2004 study by Łaszewicz discovered the prevalence at c. $88 \%$ in a sample of c. 500 Warsaw residents and a similar rate, i.e. $84 \%$, in other parts of Poland [26]. Matysiak-Budnik et al. [27] observed a similar infection prevalence rate in healthy subjects in the region of Lower Silesia. According to the paper, the prevalence of Hp infection in adults was $80-100 \%$, and decreased in younger subjects. The study was published in 1999 and its results already suggested a future fall in prevalence [25]. A decreasing tendency in the prevalence of $\mathrm{Hp}$ infection in children was also shown by Krusiec-Świergot et al. [28], who found it to be $15.7 \%$ in children of the Silesia region, while in previous studies, conducted around 2002 by Iwańczyk et al., the prevalence in children had been close to $30 \%$ [29]. Together, the above reports suggest that (i) 10-20 years ago the prevalence of $\mathrm{Hp}$ infection in Poland was very high ( $75 \%)$, and (ii) that there already was a trend towards lower prevalence in younger generations. A comparison of results for the Polish population over time are shown in Table II. Compared to previous Polish studies, we found an almost two-fold fall in the prevalence of $\mathrm{Hp}$ infection. In fact, our result is close to

Table II. Results of different studies on the prevalence of Helicobacter pylori ( $\mathrm{Hp})$ infection in adults

\begin{tabular}{|c|c|c|c|}
\hline Year of publication & Prevalence of $\mathrm{Hp}$ infection & Description & Test applied \\
\hline $1996[27]$ & $\begin{array}{c}80-100 \% \text { (depending on subjects' } \\
\text { age) }\end{array}$ & General population; Lower Silesia & Serologic tests \\
\hline $1999[25]$ & Around 55\% & $\begin{array}{c}\text { Patients with dyspepsia } \\
\text { and gastritis; } \\
\text { multi-centre study }\end{array}$ & $\begin{array}{c}\text { Urease test + histopathological } \\
\text { examination }\end{array}$ \\
\hline $2004[26]$ & Around $88 \%$ & $\begin{array}{c}\text { General population; Warsaw, } \\
\text { multi-centre study }\end{array}$ & Serologic test \\
\hline $2006[24]$ & 95\% (towns), 74\% (cities) & General population; Lublin region & Serologic test \\
\hline $\begin{array}{l}2013 \text { (material collected } \\
\text { in } 2003-2005^{\star} \text { ) [23] }\end{array}$ & $69.8 \%$ & $\begin{array}{l}\text { Patients with dyspepsia, } \\
\text { Olsztyn region }\end{array}$ & CLO test \\
\hline 2015 & $35.8 \%$ & Patients with dyspepsia; Warsaw & 13C-urea breath test \\
\hline
\end{tabular}

*Information obtained verbally. 
the prevalence rates reported in highly developed countries. The findings are also in line with the decreasing trend in prevalence rates for $\mathrm{Hp}$ infection across Europe discovered in a meta-analysis [30], which did not include Poland due to a lack of available data.

The present study focused not on the general population but on a group of patients with dyspepsia treated in two specialist clinics in Warsaw, a city whose residents' material status is higher than in the rest of the country. Our findings might also have been affected by the research method applied. The UBT allows diagnosis of a current infection, not one endured in the past, as the serological test does. Another important methodological difference between our research and the previous studies conducted in Poland is the fact that some of them examined healthy subjects, not patients with dyspepsia. The fall in prevalence of $\mathrm{Hp}$ infection may also partly result from widely applied eradication treatment and should be associated with a rise in material status and improved quality of nutrition - both well known to limit the transmission of $\mathrm{Hp}$ infection - that took place in Poland in connection with an over two-fold hike in GDP per capita in the last 15 years. A strong relationship between high prevalence rates of $\mathrm{Hp}$ infection and low socio-economic status has been proven in numerous studies [31, 32]. Nevertheless, the scale of the difference - an almost two-fold decrease suggests a considerable drop in the prevalence of $\mathrm{Hp}$ infection in Poland. This interesting trend needs to be further confirmed in large-scale epidemiological studies on the general population.

\section{Conclusions}

The current prevalence of $\mathrm{Hp}$ infection among patients with dyspepsia treated in Warsaw is $35.8 \%$, which may suggest a decrease in the frequency of $\mathrm{Hp}$ infection in Poland.

\section{Conflict of interest}

The authors declare no conflict of interest.

\section{References}

1. Bodger K, Eastwood PG, Manning SI, et al. Dyspepsia workload in urban general practice and implications of the British Society of Gastroenterology Dyspepsia guidelines (1996). Aliment Pharmacol Ther 2000; 14: 413-20.

2. van Bommel MJ, Numans ME, de Wit NJ, et al. Consultations and referrals for dyspepsia in general practice: a one year database survey. Postgrad Med J 2001; 77: 514-8.

3. Lee SY, Lee KJ, Kim SJ, et al. Prevalence and risk factors for overlaps between gastroesophageal reflux disease, dyspepsia, and irritable bowel syndrome: a population-based study. Digestion 2009; 79: 196-201.
4. Tepes B. Subgroups of dyspepsia. In: Dyspepsia in Clinical Practice. Duvnjak M (ed.), Springer Science+ Business Media, New York 2011; 9-17.

5. Tack J, Oustamanolakis P. Dyspepsia: organic versus functional. J Clin Gastroenterol 2012; 46: 175-90.

6. Tack J, Talley NJ, Camilleri M, et al. Functional gastroduodenal disorders. Gastroenterology 2006; 130: 1466-79.

7. Sugano K, Tack J, Kuipers EJ, et al. Kyoto global consensus report on Helicobacter pylori gastritis. Gut 2015; 64: 1353-67.

8. Talley NJ. American Gastroenterological Association medical position statement: evaluation of dyspepsia. Gastroenterology 2005; 129: 1753-55.

9. Talley NJ, Vakil NB, Moayyedi P. American Gastroenterological Association technical review on the evaluation of dyspepsia. Gastroenterology 2005; 129: 1756-80.

10. Castillo EJ, Camilleri M, Locke GR, et al. A community-based, controlled study of the epidemiology and pathophysiology of dyspepsia. Clin Gastroenterol Hepatol 2004; 2: 985-96.

11. Logan RPH. Urea breath test in the management of Helicobacter pylori. Gut 1998; 43: 347-50.

12. Graham DY, Malaty HM, Cole RA, et al. Simplified 13C-urea breath test for detection of Helicobacter pylori infection. Am J Gastroenterol 2001; 96: 1741-5.

13. van Blankenstein $M$, van Vuuren AJ, Looman CW, et al. The prevalence of Helicobacter pylori infection in the Netherlands. Scand I Gastroenterol 2013; 48: 794-800.

14. Krashias G, Bashiardes S, Potamitou A, et al. Prevalence of Helicobacter pylori cagA and vacA genes in Cypriot patients. J Infect Dev Ctries 2013; 7: 642-50.

15. Sarnelli G, Cuomo R, Janssens J, et al. Symptom patterns and pathophysiological mechanisms in dyspeptic patients with and without Helicobacter pylori. Dig Dis Sci 2003; 48: 2229-36.

16. Wildner-Christensen M, Møller Hansen J, Schaffalitzky De Muckadell OB. Rates of dyspepsia one year after Helicobacter pylori screening and eradication in a Danish population. Gastroenterology 2003; 125: 372-9.

17. Duggan AE, Elliott CA, Miller P, et al. Clinical trial: a randomized trial of early endoscopy, Helicobacter pylori testing and empirical therapy for the management of dyspepsia in primary care. Aliment Pharmacol Ther 2009; 29: 55-8.

18. Nandurkar S, Talley NJ, Xia H, et al. Dyspepsia in the community is linked to smoking and aspirin use but not to Helicobacter pylori infection. Arch Intern Med 1998; 158: 1427-33.

19. Dorji D, Dendup T, Malaty HM, et al. Epidemiology of Helicobacter pylori in Bhutan: the role of environment and geographic location. Helicobacter 2014; 19: 69-73.

20. Benajah DA, Lahbabi M, Alaoui S, et al. Prevalence of Helicobacter pylori and its recurrence after successful eradication in a developing nation (Morocco). Clin Res Hepatol Gastroenterol 2013; 37: 519-26.

21. Benberin V, Bektayeva R, Karabayeva R, et al. Prevalence of $\mathrm{H}$. pylori infection and atrophic gastritis among symptomatic and dyspeptic adults in Kazakhstan. A hospital-based screening study using a panel of serum biomarkers. Anticancer Res 2013; 33: 4595-602.

22. Adlekha S, Chadha T, Krishnan P, et al. Prevalence of Helicobacter pylori infection among patients undergoing upper gastrointestinal endoscopy in a medical college hospital in Kerala, India. Ann Med Health Sci Res 2013; 3: 559-63. 
23. Piotrowicz G, Stępień B, Rydzewska G. Socio-demographic characteristics of patients with diagnosed functional dyspepsia. Prz Gastroenterol 2013; 8: 354-65.

24. Celiński K, Kurzeja-Miroslaw A, Słomka M, et al. The effects of environmental factors on the prevalence of Helicobacter pylori infection in inhabitants of Lublin province. Ann Agric Environ Med 2006; 13: 185-91.

25. Jedrychowski W, Popiela T, Drews M, et al. Effect of Helicobacter pylori infection, smoking and dietary habits on the occurrence of antrum intestinal metaplasia. Clinico-epidemiological study in Poland. Pol J Pathol 1999; 50: 289-95.

26. Łaszewicz W. Wyniki badań nad zakażeniem Helicobacter pylori. Trans Humana, Białystok 2004.

27. Matysiak-Budnik T, Knapik Z, Mégraud F, et al. Helicobacter pylori infection in Eastern Europe: seroprevalence in the Polish population of Lower Silesia. Am J Gastroenterol 1996; 91 : 2513-15.

28. Krusiec-Świdergoł B, Kwiecień J, Jonderko K, et al. Zmniejszająca się częstość zakażeń Helicobacter pylori u dzieci w Polsce. Prz Gastroenterol 2010; 5: 279-84.

29. Iwańczyk F, Maciorkowska E, Kaczmarski M, et al. Badania epidemiologiczne częstości występowania Helicobacter pylori u dzieci w Polsce. Ped Wsp 2004; 6: 345-50.

30. Roberts SE, Morrison-Rees S, Samuel DG, et al. Review article: the prevalence of Helicobacter pylori and the incidence of gastric cancer across Europe. Aliment Pharmacol Ther 2016; 43: 334-45.

31. Bauer S, Krumbiegel P, Richter M, et al. Influence of sociodemographic factors on Helicobacter pylori prevalence variability among schoolchildren in Leipzig, Germany. A long-term follow-up study. Cent Eur J Public Health 2011; 19: 42-5.

32. Goh KL, Chan WK, Shiota S, et al. Epidemiology of Helicobacter pylori infection and public health implications. Helicobacter 2011; 16 Suppl 1: 1-9.

Received: 11.06 .2016

Accepted: 1.08.2016 